\title{
The impact of hard and soft quality management and proactive behaviour in determining innovation performance
}

\begin{abstract}
The extant literature has reported mixed results on the relationship between Quality Management (QM) practices and innovation performance. Most of the studies carried out to date have proposed a direct relationship between QM and innovation, while neglecting the potential variables that may influence this relationship. In order to advance in this line of research, this paper develops a model of relationships between QM, understood as a multidimensional construct (hard QM and soft QM), and innovation performance (product and process innovation), which examines the mediator role of employee proactive behaviour in these relationships. The proposed model is examined using empirical data from ISO 9001 certified firms in high technology manufacturing and service sectors. The findings from structural equation modelling show the direct influence of the hard QM dimension on product and process innovation, while the effects of the soft QM dimension are channelled via proactive behaviour. The conclusions of the present study highlight the facilitating role of QM practices and proactivity for innovation.
\end{abstract}

Keywords: Quality management; Innovation performance; Proactive behaviour. 


\section{Introduction}

One important area of research in Quality Management (QM) is the examination of the extent to which QM practices have an impact on performance (e.g. Nair, 2006; Wu and Zhang, 2013; O’Neill et al., 2016). Since innovation is a key foundation for sustainable competitive advantage, over recent years many studies have attempted to shed light on the relationship between $\mathrm{QM}$ and innovation performance. In this regard, previous contributions (e.g. Hoang et al., 2006; Martínez and Martínez, 2008; Song and Su, 2015; Jackson et al., 2016) have shown the lack of consensus over the potential effects of QM on innovation. QM practices could foster innovation due to elements such as continuous improvement, training, employee involvement or customer orientation. However, some literature shows that QM may hinder the innovation process, since standardisation associated with process management can inhibit creativity, limiting innovation to the needs of current customers (Kim et al., 2012). A review of previous contributions evidences the diversity of ways QM and innovation performance have been considered in previous research, and the lack of agreement on what kind of QM practices drive innovation performance. In this context, some authors (e.g. Zeng et al., 2015, 2017) have turned to the multidimensionality of $\mathrm{QM}$ to resolve the controversy over the QM-innovation performance link, and point to the convenience of distinguishing between hard and soft QM practices to explain this controversy. Soft QM focuses on practices such as management commitment or human resource issues, and hard QM reflects an orientation towards improving operations by way of process management and measurement.

In addition, most of the studies on the QM-innovation performance link are limited to examining direct relationships between some QM practices and innovation outcomes (e.g. Hoang et al., 2006; Silva et al., 2014; Song and Su, 2015). Few scholars have considered intervening contextual variables such as business innovation capability (Perdomo et al., 
2009a), organisational learning (Hung et al., 2011), cultural change (Moreno et al., 2013) or dynamic capabilities (Camisón and Puig, 2016). Zeng et al. (2017) point to the need for more studies considering the role other variables could play in the QM-innovation relationship. In this vein, Hackman and Wageman (1995) previously highlighted the need to analyse how employees actually behave at work, since the work processes condition the potential effects of QM on performance. Likewise, Adhikari (2010) also argues that performance is a multidimensional concept referring not only to the achievement of the agreed results but also to the execution of the work itself, that is, behaviour and attitudes at work. It thus seems appropriate to address the relationship between QM and innovation performance by focusing on employee behaviours. Therefore, the present study considers proactive behaviour as an intervening variable, as it encourages employees to anticipate or initiate change, which is increasingly necessary to ensure the success of the company, and organisations often rely on proactive employees to foster innovation (Grant and Ashford, 2008; Fritz and Sonnentag, 2009).

Finally, previous contributions have focused on a wide sample of multisector organisations, mainly in manufacturing activities, and some researchers (e.g. Prajogo and Hong, 2008) have identified the need for studies that cover high-tech companies, where innovation behaviour is paramount. To the best of our knowledge, only the studies by Perdomo et al. (2009a) and Hung et al. (2011) have examined the QM-performance link in the high-tech environment, and more research is needed in this context.

Taking into account the state of the art in the QM-innovation relationship, the purpose of this study is to analyse the relationship between hard and soft dimensions of QM and innovation performance (product and process innovation) in high technology sectors, incorporating the proactive behaviour of employees as a mediating variable in this link. Several contributions emerge from this work. Firstly, we contribute to the research by 
focusing on a range of QM practices, both social and technical, and analysing their potential effect on proactive behaviour of employees and innovation performance. Secondly, while previous papers have mainly focused on a direct relationship between QM and some specific kinds of innovation, this paper brings to the table the importance of employees' behaviour in this relationship. Finally, the contextualisation of our study in high-tech sectors will shed some light on the extent to which QM is able to enhance innovation in a technologically dynamic context.

To achieve our purpose, in the following section we outline the existing theoretical relationships between QM, proactive behaviour and innovation performance. We then describe the research methodology used and present the results of an empirical study on a sample of high-tech sectors. Lastly, the findings from the study are discussed and the conclusions presented.

\section{Conceptual framework}

In this section we conceptually define the variables used in our model and present a review of the literature from which the hypotheses are formulated.

\subsection{Hard and soft QM dimensions}

Previous contributions consider QM as an approach to management characterised by certain concepts and practices that, if used consistently, enable continuous performance improvement (e.g. Nair, 2006; Bou et al., 2009; Ebrahimi and Sadeghi, 2013; Laosirihongthong et al., 2013). The QM literature has traditionally considered the existence of various QM dimensions, maintaining that practices can be classified into two broad categories: social or soft QM, and technical or hard QM (Prajogo and Sohal, 2004; Bou et al., 2009; Song and Su, 2015; Zeng et al., 2015, 2017). Song and Su (2015) suggest that although scholars use different terms to label QM practices, soft and hard QM can be 
considered as equivalents to the distinction between core and infrastructure management practices proposed by authors such as Flynn et al. (1995).

Factors proposed by Powell (1995) are used to represent hard and soft QM practices in the present study. Table 1 reports the QM practices classified according to previous contributions that distinguish between hard and soft QM.

Table 1. Hard and Soft QM Practices in the present study

\begin{tabular}{|c|c|}
\hline \multicolumn{2}{|l|}{ HARD QM PRACTICES } \\
\hline $\begin{array}{l}\text { Benchmarking: researching and observing best competitive } \\
\text { practices }\end{array}$ & Powell (1995), Gadenne and Sharma (2009) \\
\hline $\begin{array}{l}\text { Zero-defects mentality: a system in place to spot defects as } \\
\text { they occur }\end{array}$ & Powell (1995), Gadenne and Sharma (2009) \\
\hline $\begin{array}{l}\text { Process improvement: reducing waste and cycle times in all } \\
\text { areas through cross-departmental process analysis, where } \\
\text { activities and resources are handled as processes }\end{array}$ & $\begin{array}{l}\text { Powell (1995), Prajogo and Sohal (2004), Naor et al. } \\
\text { (2008), Laosirihongthong et al. (2013), Song and Su } \\
\text { (2015), Zeng et al. (2015, 2017) }\end{array}$ \\
\hline $\begin{array}{l}\text { Measurement: goal orientation and zeal for data, with } \\
\text { performance measurement, often using statistical methods }\end{array}$ & $\begin{array}{l}\text { Powell (1995), Prajogo and Sohal (2004), Gadenne and } \\
\text { Sharma (2009), Naor et al. (2008), Laosirihongthong et } \\
\text { al. (2013), Song and Su (2015), Zeng et al. (2015, 2017) }\end{array}$ \\
\hline \multicolumn{2}{|l|}{ SOFT QM PRACTICES } \\
\hline $\begin{array}{l}\text { Management commitment: top managers' long-term } \\
\text { commitment to the QM philosophy }\end{array}$ & $\begin{array}{l}\text { Powell (1995), Prajogo and Sohal (2004), Rahman and } \\
\text { Bullock (2005), Naor et al. (2008), Gadenne and } \\
\text { Sharma (2009), Laosirihongthong et al. (2013), Song } \\
\text { and Su (2015) }\end{array}$ \\
\hline $\begin{array}{l}\text { Adopting the philosophy: using tools like mission statement, } \\
\text { and themes and slogans to communicate QM philosophy }\end{array}$ & $\begin{array}{l}\text { Powell (1995), Rahman and Bullock (2005), Gadenne } \\
\text { and Sharma (2009), Laosirihongthong et al. (2013) }\end{array}$ \\
\hline $\begin{array}{l}\text { Closer to customers: determining customers' (both inside and } \\
\text { outside the firm) requirements and then meeting them }\end{array}$ & $\begin{array}{l}\text { Powell (1995), Rahman and Bullock (2005), Naor et al. } \\
\text { (2008), Gadenne and Sharma (2009), Laosirihongthong } \\
\text { et al. (2013), Song and Su (2015) }\end{array}$ \\
\hline $\begin{array}{l}\text { Closer to suppliers: working closely and cooperatively with } \\
\text { suppliers }\end{array}$ & $\begin{array}{l}\text { Powell (1995), Rahman and Bullock (2005), Naor et al. } \\
\text { (2008), Gadenne and Sharma (2009), Laosirihongthong } \\
\text { et al. (2013) }\end{array}$ \\
\hline $\begin{array}{l}\text { Increased training: usually includes QM principles, team } \\
\text { skills and problem solving }\end{array}$ & $\begin{array}{l}\text { Powell (1995), Rahman and Bullock (2005), Gadenne } \\
\text { and Sharma (2009), Zeng et al. (2015, 2017) }\end{array}$ \\
\hline $\begin{array}{l}\text { Open organisation: work teams, open horizontal } \\
\text { communications, and relaxation of traditional hierarchy }\end{array}$ & $\begin{array}{l}\text { Powell (1995), Prajogo and Sohal (2004), Rahman and } \\
\text { Bullock (2005), Naor et al. (2008), Gadenne and } \\
\text { Sharma (2009), Laosirihongthong et al. (2013), Song } \\
\text { and Su (2015), Zeng et al. (2015, 2017) }\end{array}$ \\
\hline $\begin{array}{l}\text { Employee empowerment: increase employee involvement in } \\
\text { design and planning and greater autonomy in decision } \\
\text { making }\end{array}$ & $\begin{array}{l}\text { Powell (1995), Prajogo and Sohal (2004), Rahman and } \\
\text { Bullock (2005), Naor et al. (2008), Gadenne and } \\
\text { Sharma (2009), Laosirihongthong et al. (2013), Song } \\
\text { and Su (2015), Zeng et al. (2015, 2017) }\end{array}$ \\
\hline
\end{tabular}

Source: the authors, based on Powell (1995) 
According to the above contributions, soft QM gathers the human features of QM, while hard QM covers practices based on technical and methodological issues. In order to be effective, hard and soft QM should be interrelated, thus shaping what Jayaram et al. (2010) called "a socio-technical mix" of practices. Soft and hard QM issues cannot be managed in isolation because both dimensions are needed for successful QM implementation (Hackman and Wageman, 1995; Zu, 2009).

\subsection{Innovation performance}

Innovation has been conceptualised in many ways and studied from several perspectives. We based our definition on Damanpour (1991: 556), who describes innovation as the adoption of an internally generated or purchased device, system, policy, programme, process, product, or service that is new to the adopting organisation. Although different types of innovation have been described in the literature, three typologies have attracted most attention (Damanpour, 1992), each centring on a pair of innovation types: product and process, radical and incremental, and administrative and technical. In this study, we focus on product and process innovation as a categorisation of innovation performance. Product innovations are new products or services introduced to meet an external user need, and process innovations are new elements introduced into a firm's production or service operation to produce a product or render a service (Ettlie, 1990; Damanpour, 1991; Bauer and Leker, 2013). The categorisation of innovation dimensions as product and process is important because each type of innovation requires different organisational skills. Product innovations require firms to observe and assimilate patterns of customer needs, and then design and manufacture the product, while process innovations imply firms applying technology to improve the efficiency of production procedures (Ettlie et al., 1984). 


\subsection{Hard and soft $\mathrm{QM}$ and innovation performance}

Scholars such as Prajogo and Sohal (2001), Martínez and Martínez (2008), Song and Su (2015) or Zeng et al. $(2015,2017)$ suggest that the discrepancies in the relationship between QM and innovation performance may be due to different interpretations of QM, which includes varied kinds of practices. It is therefore important to define QM in terms of hard and soft elements in order to resolve the controversies in the literature, since it would shed light on which dimension bears most responsibility for innovation performance.

\section{Hard QM and innovation}

Conflicting arguments are found in the literature on the relationship between the hard dimension of QM and innovation. When a QM initiative focuses on these more mechanistic aspects, formalisation can make employees trust the same routines, creating a comfort zone that shuns change and, in turn, innovation (Prajogo and Sohal, 2004; Santos and Álvarez, 2007; Sadikoglu and Zehir, 2010; Moreno et al., 2013). The literature on how QM can hinder innovation argues that the standardisation associated with managing processes can lead to linear thinking, resistance to change and may generate only incremental innovation or reduce it to customers' current needs (Benner and Tushman, 2003; Prajogo and Sohal, 2004, Singh and Smith, 2004). Likewise, as QM encourages reduced variation in organisational processes, and many ideas related to innovation result from such variation (Song and $\mathrm{Su}, 2015$ ), the result may actually be a reduction in innovation.

However, other opinions are voiced in the literature. In this vein, following Kim et al. (2012) or Manders et al. (2016), the management of processes and the search for zerodefects can lead to process innovation by identifying critical activities, and can engender improvements by repeating and enhancing routines through problem solving and experimentation. At the same time, these QM practices are likely to contribute to product innovation. As Ooi et al. (2012) contend, process management entails applying new 
technologies, which derive in new design features for products. Moreover, having a process perspective may lead to new product development being considered as a process (Song and $\mathrm{Su}, 2015$ ), and create routines to increase efficiency and reduce cycle times in developing new products, and respond more rapidly to changing markets. As Moreno and Lloria (2008) point out, standardisation is not necessarily a drawback for innovation but, as innovation does not occur spontaneously, it can help improve knowledge creation and diffusion by directing actions and behaviours. Kim et al. (2012: 300) explicitly state that "formal routines provide a crucial framework for guiding a radical innovation project in terms of budget and time".

In addition, the culture of measurement and making decisions based on timely information, as well as obtaining information by way of benchmarking, provide the opportunity for process innovation. According to Sadikoglu and Zehir (2010) or Ooi et al. (2012), these practices contribute to identify non-value added activities, signalling needs to renovate processes or replace them with other more effective ways of working. Moreover, benchmarking helps to identify new technologies and production processes in other firms that could be applied in the organisation. Likewise, managing quality information and having immediate feedback from customers helps to speed up new products to the market (Flynn, 1994).

In brief, Zeng et al. (2015) summarise how hard QM could improve innovation performance: quality tools and techniques help to introduce order and create routine-based organisations, and the established routines encourage employees to pay attention to and understand vital processes, the cause of problems, and the search for new and innovative solutions. Silva et al. (2014) also recognise that hard QM practices promote creativity and reduce fear, which may lead to both improvement of processes and product innovation. 


\section{Soft QM and innovation}

As for the soft dimension, Prajogo and Sohal (2004) explain that soft QM is associated with an organismic model (Spencer, 1994), which has been identified as instrumental in supporting innovation. Martínez and Martínez (2008) and Zeng et al. (2015) note that QM practices are in accordance with what Pfeifer et al. (1998) identify as fundamental aspects for innovation: customer orientation, promotion of flexible organisational structures, and employee autonomy. In the same vein, Song and Su (2015) highlight that the enablers of innovation are essentially the same elements as the characteristic features of QM, such as teamwork, employee involvement and supplier participation.

Regarding customer orientation, although some voices warn that QM organisations may be narrow-minded and limit their focus to the needs of current customers (Slater and Narver, 1998), customer orientation is likely to stimulate firms to search for new customer needs and feedback, which has been understood to trigger product innovation so as to continuously meet changing and latent market needs (Santos and Álvarez, 2007; Sadikoglu and Zehir, 2010; Manders et al., 2016). This customer orientation derives in the concept of the internal customer, which according to Terziovski and Guerrero (2014) may foster process innovation by facilitating cooperation among functions and resolving work procedure inconsistencies.

In addition, as Silva et al. (2014) recognise, product innovation benefits from the valuable information, expertise and specialised capabilities that come with suppliers' involvement in the design and development of products. Similarly, knowledge sharing with suppliers may help to identify areas for improvement and innovation in processes.

Moreover, findings from Jackson et al. (2016) and Manders et al. (2016) suggest that management support for quality and communication of QM philosophy could foster innovation by establishing a shared vision and challenging targets that inspire employees to 
high levels of performance, encourage training, and promote recognition of employees' suggestions and creative performance. These elements enable managers to create a fertile environment that nourishes employee contributions and cultivates new initiatives and innovation projects, thereby leading to process and product innovation. For instance, managers can provide resources for training or allocate time during working hours for employees to participate in improvement groups (Jackson et al., 2016). In fact, Flynn (1994) found that top management leadership helps to speed up product innovation, and Kim et al. (2012) evidenced a direct relationship between management leadership and process innovation.

Authors such as Prajogo and Cooper (2010) argue that the human resource management practices associated with the soft dimension of QM (training, empowerment, promotion of an open organisation) are essentially equivalent to high performance work practices (HPWP) (Wood and Albanese, 1995; Combs et al., 2006). HPWP stimulate broad training, empowerment, teamwork and internal communications systems, which encourage an organisational context of autonomy and trust that nudges behaviour towards knowledge sharing and new-idea generation for innovative new products and processes. This claim is justified by the results of previous research such as Jiménez and Sanz (2008), who concluded that training, participation, communication or teamwork significantly explain product and process innovation. For their part, Santos and Álvarez (2007) and Ooi et al. (2012) recognise that training and developing employees' knowledge and skills prepare them to better perform their jobs, be more open to new systems, and even to propose new operation procedures. Regarding product innovation, teamwork or the development of a shared vision promote absorptive capacity, which is considered to be an antecedent of product innovation (Silva et al., 2014). Moreover, empowered employees are able to use new techniques to identify opportunities for new product development and may even 
provide a more rapid response by handling problems at the source (Flynn, 1994; Song and

$\mathrm{Su}, 2015)$.

To sum up, soft QM could nurture a fertile environment and supportive culture for innovation by enabling the efficient detection of customer needs, going beyond conforming to standards, promoting knowledge sharing among employees and with suppliers, enhancing employees' capabilities, commitment and participation. All this will lead to the continuous improvement of work processes and an effective translation of ideas into new products that customers value (Prajogo and Sohal, 2001; Martínez and Martínez, 2008; Perdomo et al., 2009a; Sadikoglu and Zehir, 2010; Kim et al., 2012, Silva et al., 2014).

The empirical studies that analyse the QM-innovation performance link also support the positive relationship between soft and hard QM and innovation (see Table 2).

Table 2: A summary of the empirical evidence for the soft and hard QM-innovation performance link

\begin{tabular}{|c|c|c|}
\hline Authors & QM practices considered & $\begin{array}{c}\text { Critical QM practices driving innovation } \\
\text { performance }\end{array}$ \\
\hline $\begin{array}{l}\text { Prajogo and } \\
\text { Sohal (2004) } \\
\text { Feng et al. } \\
(2006)\end{array}$ & $\begin{array}{l}\text { Three QM subgroups: QM1 (leadership and } \\
\text { people management); QM2 (customer focus } \\
\text { and process management); QM3 (strategic } \\
\text { planning and information and analysis) }\end{array}$ & $\begin{array}{l}\text { Soft QM elements: leadership and } \\
\text { people management are related to product } \\
\text { innovation. }\end{array}$ \\
\hline $\begin{array}{l}\text { Hoang et al. } \\
\text { (2006) }\end{array}$ & $\begin{array}{l}11 \text { QM practices: top management } \\
\text { commitment, employee involvement, employee } \\
\text { empowerment, education and training, } \\
\text { teamwork, customer focus, process } \\
\text { management, information and analysis, } \\
\text { strategic planning, open organisation, service } \\
\text { culture }\end{array}$ & $\begin{array}{l}\text { Both hard and soft: when considered as separate } \\
\text { practices, not all QM practices enhance } \\
\text { innovation. Only leadership and people } \\
\text { management, education and training, process and } \\
\text { strategic management, and open organisation } \\
\text { showed a positive impact on the firm's innovation } \\
\text { performance. }\end{array}$ \\
\hline $\begin{array}{l}\text { Kim et al. } \\
(2012)\end{array}$ & $\begin{array}{l}8 \mathrm{QM} \text { practices: management leadership, } \\
\text { training, employee relations, supplier quality } \\
\text { management, customer relations, } \\
\text { product/service design, quality data and } \\
\text { reporting and process management }\end{array}$ & $\begin{array}{l}\text { Direct effect of hard QM: overall process } \\
\text { management is a significant and direct predictor of } \\
\text { five types of innovation. Other kinds of practices } \\
\text { are indirectly associated with innovation }\end{array}$ \\
\hline $\begin{array}{l}\text { Ooi et al. } \\
\text { (2012) }\end{array}$ & $\begin{array}{l}\text { Leadership, customer focus, strategic planning, } \\
\text { people management, information analysis and } \\
\text { process management }\end{array}$ & $\begin{array}{l}\text { Both hard and soft: process management, strategic } \\
\text { planning, people management and customer focus } \\
\text { have a positive influence on innovation } \\
\text { performance }\end{array}$ \\
\hline $\begin{array}{l}\text { Silva et al. } \\
\text { (2014) }\end{array}$ & $\begin{array}{l}\text { QM practices classified into } 3 \text { groups: QM } \\
\text { culture (management commitment, human } \\
\text { resource management, customer focus); process } \\
\text { improvement capability (statistical process } \\
\text { control, quality information, benchmarking); } \\
\text { product design capability (supplier } \\
\text { involvement, FMEA, design quality } \\
\text { management) }\end{array}$ & $\begin{array}{l}\text { Direct effect of hard QM: only the group of QM } \\
\text { practices concerning product design capability has } \\
\text { a direct effect on product innovation }\end{array}$ \\
\hline
\end{tabular}




\begin{tabular}{|l|l|l|}
\hline $\begin{array}{l}\text { Song and } \mathrm{Su} \\
(2015)\end{array}$ & $\begin{array}{l}\text { Infrastructure QM practices (leadership, quality } \\
\text { strategy planning, customer focus, human } \\
\text { resource management) } \\
\text { Core QM practices (process management, } \\
\text { information and analysis, supplier management, } \\
\text { product design and manufacture) }\end{array}$ & $\begin{array}{l}\text { Infrastructure QM practices promote new product } \\
\text { development }\end{array}$ \\
\hline $\begin{array}{l}\text { Zeng et al. } \\
(2015,2017)\end{array}$ & $\begin{array}{l}\text { 2 constructs: } \\
\text { hard (process management and quality } \\
\text { information) } \\
\text { soft (group problem solving, employee } \\
\text { suggestion, task-related training) }\end{array}$ & $\begin{array}{l}\text { Direct effect of hard QM on innovation } \\
\text { performance }\end{array}$ \\
\hline
\end{tabular}

Source: the authors

Some studies (e.g. Hoang et al., 2006; Ooi et al., 2012) report that both hard and soft QM practices have a significant impact on innovation. Other studies emphasise the role of either hard or soft QM dimensions. One stream of literature highlights the soft elements as being critical to realise full innovation advantages from QM practices (e.g. Prajogo and Sohal, 2004; Feng et al., 2006; Song and Su, 2015). In contrast, authors such as Kim et al. (2012) conclude that process management plays a predominant role in improving innovation performance when supported by a set of interrelated soft and hard QM practices. Similarly, Silva et al. (2014) and Zeng et al. (2015) find that technical practices are critical for product innovation, while a QM culture, teamwork, empowerment and training are necessary supporting practices. In light of the above arguments the following hypotheses can be stated:

\section{Hypothesis 1: Hard QM has a positive relationship with innovation performance}

Hypothesis 2: Soft QM has a positive relationship with innovation performance

\subsection{QM dimensions and proactive behaviour}

The behavioural perspective in the human resource management literature assumes that employee behaviours are the most relevant factor to attain the desired performance levels in the firm (Miles and Snow, 1984; Schuler and Jackson, 1987). In particular, we focus on the role of proactive behaviour to increase firms' innovation results. This type of behaviour refers to "self-initiated and future-oriented action that aims to change and improve the 
situation or oneself" (Parker et al., 2006; 2010). Proactive employees take the initiative at work to challenge the status quo rather than adapting to the conditions

(Crant, 2000: 436). Many of the prior studies in the field of proactivity have considered proactive behaviour as an individual construct. However, in this study we are interested in the collective proactive behaviour of a group of employees (those belonging to the area of product/service development). Collective variables are of great interest in the literature given their close relationship with organisational results (Pugh and Dietz, 2008). Thus, similar to previous studies (e.g. Erkutlu and Chafra, 2012) we define collective proactive behaviour as the extent to which an area engages in self-starting, future-focused actions that try to modify the external situation or the department. We refer to how the unit as a whole is perceived, that is, the standard mode of behaviour in the unit. Hence, collective proactive behaviour differs in structure from average individual-level proactivity because it captures interactive elements of the construct not included at the individual level of analysis (e.g. social interactions) (Morgeson and Hofmann, 1999; Kozlowski and Klein, 2000; Ehrhart, 2004).

Some of the dimensions of the hard side of QM such as measurement and benchmarking emphasise providing employees with information about quality performance and productivity (Zeng, 2015, 2017). Studies in the field of proactivity have suggested that the decision to engage in proactive behaviours requires information, for several reasons. First, if employees are given valuable information about the firm and their work, they perceive that the organisation trusts them, which through the norm of reciprocity (Blau, 1964), motivates them to show proactive behaviours at work in return (Maden, 2015). Second, the quality of information provided to employees also allows employees to understand potential problems and opportunities (Frese and Fay, 2001), thus helping them to predict, understand and influence their environments in advance (Grant and Ashford, 2008). Third, 
information about competitors, processes and organisational results help the alignment between employees' behaviours and organisational objectives. This type of information allows employees to understand how they may influence the firm results, which enhances feelings of accountability and, as a result, improves their willingness to be proactive (Fuller et al., 2006). With more information, employees can better concentrate on improving their work rather than being distracted by feelings of uncertainty about the results of their contributions (Maden, 2015).

The hard dimension of QM also emphasises process management through a set of techniques used to improve processes and to introduce a mentality of zero defects in the firm (Zeng, 2015, 2017). When processes operate as expected, a certain degree of routinisation is achieved, which can contribute to higher employee proactivity. Processes without errors free employees' cognitive resources and give them time to think about other aspects of work, discover new ways of solving problems and come up with new ideas (Ohly et al., 2006). According to this reasoning, we expect that:

\section{Hypothesis 3: Hard QM has a positive relationship with proactive behaviour}

The soft dimension of QM emphasises the human aspects of the system, including many of the elements of a high commitment approach to the management of human resources, as explained above. Thus, through its emphasis on employee training, soft QM helps to develop employees' knowledge, skills and abilities (KSAs) (Escrig et al., 2012). Proactive behaviours depend on employee cognitive ability; in other words these behaviours can be developed better if employees are good at their jobs, and are able to learn quickly (Frese and Fay, 2001). As soft QM contributes to developing KSAs, employees assume that they can actually do something about improving work and effectiveness, thus increasing the likelihood of their engaging in proactive behaviours (Frese and Fay, 2001). Additionally, the soft dimension of QM includes initiatives to give employees greater participation and 
control at work by promoting empowerment and open and flexible structures, which could be potential antecedents of proactive behaviours. With higher control at work, employees tend to expect that future job situations will also be controllable, thus increasing their willingness to behave proactively (Frese and Fay, 2001; Unsworth and Parker, 2003). Several studies demonstrate that control at work and autonomy influence proactive behaviours (Frese et al., 1996; Speier and Frese, 1997; Ohly et al., 2006; Parker et al., 2006; Shin and Kim, 2015). Furthermore, through customer and supplier involvement, soft QM broadens job boundaries, increasing employees self efficacy to carry out tasks beyond the traditional prescribed technical requirements (Parker, 1998). As proactive behaviours entail a high potential psychological risk to the individual (e.g. proactive employees may have to deal with others' resistance and scepticism), self efficacy gives employees the confidence they need to cope with the consequences of proactivity, as demonstrated by several studies (Axtell et al., 2000; Parker et al., 2006; Strauss et al., 2009; Ohly and Fritz, 2007). Finally, by showing strong managerial commitment to the implementation of QM and by acting as leaders in adopting the QM philosophy, managers can play a key role in enhancing proactivity in the workforce. Support from leaders is crucial in the promotion of these types of behaviours because leaders contribute to reducing the potential uncertainties and risks associated with proactivity. Committed leaders help to establish a supportive environment in which employees are encouraged to try alternative ways of doing their jobs without worrying about potential obstacles (Crant, 2000; Wu and Parker, 2017), as diverse studies (e.g. Axtell et al., 2000; Ramus and Steger, 2000) have demonstrated. For these reasons, we expect that:

\section{Hypothesis 4: Soft QM has a positive relationship with proactive behaviour}

\subsection{Proactive behaviour and innovation performance}

Some authors (e.g. Frese and Fay, 2001; Unsworth and Parker, 2003) suggest that proactive 
behaviour is an important driver of innovation. The self-starting component of proactive behaviour is relevant to creativity, particularly to identifying problems and generating novel solutions (West, 2002; Anderson et al., 2014). Nevertheless, proactive employees not only have a relevant role in identifying opportunities for innovation, but also in implementing innovations. For example, in the development of service innovations, employees play a key role not only in detecting customers' needs and preferences as a result of their direct contact with them, but also in implementing the innovation. Engineers also make a significant contribution to the creation, development and generation of new knowledge (Menzel et al., 2007), and their technical expertise and skills are an important source for manufacturing innovation. Hence, their initiative and proactive behaviour contribute significantly to the achievement of firm innovation (Unsworth and Parker, 2003).

There are several reasons why proactive employees might contribute to innovation performance. First, proactive behaviours encourage employees to anticipate or initiate change, and organisations often rely on proactive employees to foster innovation (Grant and Ashford, 2008). As some authors suggest (e.g. Griffin et al., 2007; Parker and Collins, 2010), innovation is fostered by employees' proactive behaviours, since proactivity is the predisposition to favour change and carry out actions to influence the environment (Bateman and Crant, 1993; Crant, 2000). Second, in dynamic technological environments, where work becomes more decentralised and pressures for innovation increase, employees are required to work without close supervision (Unsworth and Parker, 2003) and proactive behaviour takes on a more critical role in organisational success (Crant, 2000). Proactive and innovative behaviours are necessary in such situations (Parker, 1998; Crant, 2000). Third, employees represent a key source of innovative and useful ideas for developing new products, services, and procedures; in the words of Unsworth and Parker, (2003: 176), "they know what is going on, what customers want and need, what inefficiencies lie in the 
system". Based on these arguments, we propose that proactive behaviour will improve firm innovation performance.

Hypothesis 5. Proactive behaviour has a positive relationship with innovation performance.

The above theoretical and empirical arguments lead us to posit a final hypothesis regarding the mediator role of proactive behaviour. As explained by Sadikoglu and Zehir (2010), when employees are treated as valuable assets, participate in continuous process improvement and are not blamed for the failures of the system, they can show initiative and take risks, which derive in increased innovation performance. All the hypothesised relationships are modelled as depicted in Figure 1.

Hypothesis 6. Proactive behaviour mediates the relationship between soft and hard QM and innovation performance.

Figure 1. Conceptual model

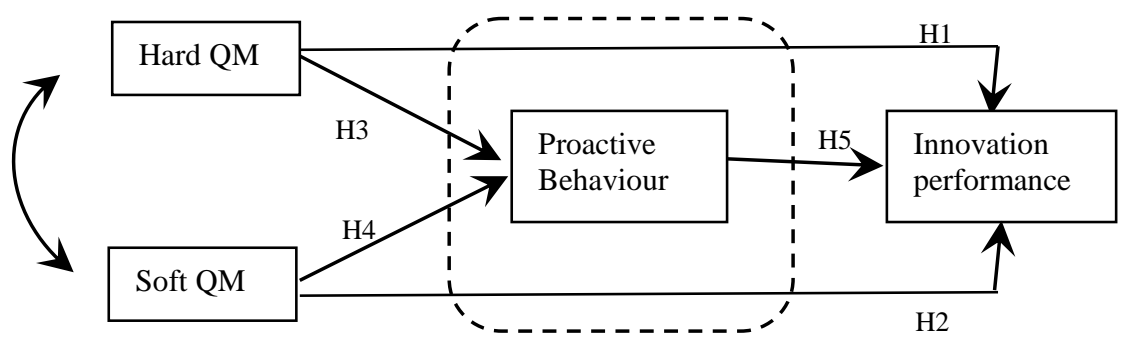

H6

\section{Methodology}

\subsection{Data}

The data to test the hypotheses were obtained from a sample of Spanish firms listed in the Spanish SABI Database from two sectors: chemical manufacturing sector (CNAE 20) and information technology (IT) service sector (CNAE 62). These sectors are considered to have a high to medium intensity in $R \& D$ expenditure, as recognised by the Spanish 
National Institute of Statistics 2015. We focus on one industrial and one service sector, as most studies on the relationship between QM and innovation use samples with manufacturing and services industries (e.g. Prajogo and Sohal, 2004, 2006; Santos and Álvarez, 2007).

These specific sectors were chosen for two primary reasons. First, they were among the most innovation-oriented sectors in terms of their percentage of innovative firms and $\mathrm{R} \& \mathrm{D}$ investments, according to the Spanish National Institute of Statistics 2015. Second, the firms selected should have a minimum size in order to have a person responsible for the area of product/service development who can report on issues of innovation performance. Consequently, we needed to select firms with 50 workers or more in the case of the manufacturing sector, and with 20 employees or more for the service sector, following the criteria used in previous studies (Pekovic and Galia, 2009; Llach et al., 2011). Chemical and IT services were the sectors with the highest number of firms meeting these criteria, according to the data from the 2015 Spanish SABI database. A valid population of 337 firms in the chemical sector and 1,194 in the IT service sector meeting these criteria were obtained from SABI. Our intention was to approach all the firms in the population, but we were unable to make contact with 31 firms in the chemical sector and 210 firms in the IT service sector.

The data were collected from May to October 2016 through an e-mail survey, after being pretested by quality and innovation managers from five companies. As in the study of Prajogo and Sohal $(2004,2006)$, if the firm has several plants the focus of our research was limited to one site per firm, and for smaller organisations (i.e., single site) we focused on the entire firm. Two informants per firm were approached: the quality manager answered questions regarding QM practices, and the person in charge of the area of development of products/services reported on issues of innovation performance and proactive behaviour. 
By doing so, our intention was to match the kind of information required with the relevant informant and overcome any simultaneity bias in the responses. First, the firms in the dataset were contacted by telephone to obtain the names of the quality director and the person in charge of the innovation area, in order to elicit their participation and ask for an email address. We ensured that the targeted firm had a QM initiative and specific staff working on product/service development in the same location. Firms were informed of the purpose and relevance of the research project and the confidentiality of the responses, and were told they would receive a report on the research results as an incentive for them to take part in the study. Once contact had been made, information about the research was sent via e-mail to the informants with a link to the corresponding questionnaire. The questionnaire to the person responsible for product/service development clearly specified that the questions about proactive behaviour referred to employees in this area. Repeated follow-up contact was made with late responding informants.

As in previous studies, such as Kim et al. (2012), we were interested in certified firms, which means that they are familiar with QM practices and, therefore, fit the research purposes. Focusing on certified organisations also avoids bias, since certification may imply substantial changes in the organisations which could mean their innovation performances differ from those of non-certified organisations (Manders et al., 2016).

Taking into account this criterion, we obtained both completed questionnaires from 173 ISO 9001 certified firms: 84 firms from the chemical manufacturing sector and 89 from the IT service sector. Forty-three additional firms completed just one of the questionnaires and were not considered in the study. The sample error in our study was $\pm 7.02 \%$ for the whole sample. Of the 173 companies, 20.81\% had fewer than 50 employees (small companies), $59.54 \%$ had between 50 and 249 employees (medium-sized companies), and $19.65 \%$ had 250 employees or more (large companies). The average number of employees per firm for 
the whole sample was $352.35(S D=1,049.72)$.

\subsection{Assessment of common method and nonresponse bias}

Several procedural measures were used to help avoid common method bias by increasing the motivation to respond accurately, as suggested by Podsakoff et al. $(2003,2012)$ and Brannick et al. (2010). First, two informants were approached in every firm, one reporting information on the dependent variable and other on the independent variable. Second, we provided a suitable cover story and instructions, and assured respondents that there were no right or wrong answers, and that they should respond to items as they saw fit and as sincerely as possible. Third, we labelled each section of the questionnaires clearly and provided titles with the different variables included, and also separated items for the dependent and mediator variables to avoid proximity effects. Finally and as explained earlier, we gathered data through online questionnaires as opposed to face-to-face interviews. We also applied some statistical remedies commonly recommended to control for common method bias. We carried out a single-factor test (Podsakoff et al., 2003) as in many other empirical studies (e.g. Kim et al., 2012). The results of the CFA with all the indicators loading on a single-factor $\left(\mathrm{S}-\mathrm{B} \chi^{2}(1377)=3937.3769, \mathrm{p}=0.0000 ; \mathrm{B}-\mathrm{BNFI}=0.338\right.$; $\mathrm{CFI}=0.433$; $\mathrm{RMSEA}=0.105)$ revealed a poor fit, suggesting that common method bias is not a problem in this study. Further, we tested for validity following Silva et al.'s (2014) procedure. We correlated responses for one covariate included in the model -firm sizewith data from the SABI database. Results show a significant correlation between data from the two sources $(p<0.01)$ for the firm size variable.

The presence of non-response bias was checked with two common procedures (Armstrong and Overton, 1977). First, we used the "comparison with known values for the population" method, comparing the number of employees and the operating income (available in the 
SABI database) of the sample firms with this information for the firms of the population that did not participate. The results of the $t$-tests $(\mathrm{t}=0.32 ; \mathrm{p}>0.05$ for size and $\mathrm{t}=0.74 ; \mathrm{p}>0.05$ for operating income) showed no significant differences between the two groups of firms. In addition to this, we carried out the time trend extrapolation test by performing a $t$-test on the scores of the early and late respondents. No significant differences $(p>.05)$ were found between them in any of the independent, mediator, dependent or control variables. Therefore, the above analyses revealed no evidence of non-response bias in our study.

\subsection{Measures}

The measurement instruments used in this research are presented in Appendix A. The questionnaire was designed on the basis of the literature review, so the instruments used to measure the different constructs were taken from validated scales. Because the original scales were in English, we followed standard translation and back-translation procedures to produce the Spanish versions as recommended in the literature (e.g. Ghauri et al., 1995). All variables were measured using a five-point Likert scale.

To measure QM practices we used Powell's (1995) scale, which has been widely adopted in the literature, for instance in the recent study by Carmona et al. (2016). Following previous studies (e.g. Prajogo and Sohal, 2004; Zeng et al., 2015, 2017), the QM practices in this scale were separated into two factors -soft QM and hard QM- as presented in Table 1.

Innovation performance was measured using Prajogo and Sohal's (2006) scale, which distinguish between product and process innovation. For each one, these authors capture different aspects of innovation performance such as number of innovations, speed, newness and being the first in the market. In consequence, as these authors highlight, the measurement of product and process innovation "captures areas that could be considered as radical innovation" (Prajogo and Sohal, 2006: 301). Other previous studies (e.g. Singh and 
Smith, 2004; Hung et al., 2011, Ooi et al., 2012) have also followed the distinction between product and process innovation, the most traditional one according to Zeng et al. (2015).

We used the seven-item scale developed by Frese et al. (1997) to assess collective proactive behaviour. Although this scale was originally created to assess individual proactive behaviours, prior empirical studies have shown its validity to assess collective proactive behaviours (e.g. Baer and Frese, 2003).

Previous research has shown that company characteristics such as size and sector may affect innovation performance (Perdomo et al., 2009b; Sadikoglu and Zehir, 2010; Camisón and Puig, 2016). We therefore controlled for firm size (measured by the logarithm of the number of employees $)$ and the sector as a dummy $(0=$ information technology service activities; $1=$ chemical manufacturing). In addition, as standardisation of innovation practices can favour innovation (Perdomo et al., 2009b; Mir et al., 2016), we considered technological management system certification as a control variable (measured as a dichotomous variable).

\subsection{Analytical procedure}

The relationships proposed were tested by way of structural equation models in the EQS statistical program (Bentler, 2006). We followed the two-step procedure usually recommended in SEM. The measurement models of the studied variables were fitted in the first step and the structural model, including the relationships among them, in a second step. To reduce the complexity of this model, the composite measure of each construct was used (Landis et al., 2000), calculating the mean value of their indicators. A path analysis was thus specified, using maximum likelihood (ML) as the estimation method. 


\section{Results}

\subsection{Scale validation}

Confirmatory Factor Analysis (CFA) was used to examine the properties of the measurement model, following the recommendations of Fornell and Larcker (1981) and Ahire and Devaraj (2001). Because sample size restrictions mean that including a large number of indicators would render the measurement model too complex, we followed Bentler and Chou's (1987) suggestion to examine submodels, grouping related constructs. This is a recognised methodology in the literature on QM and innovation (e.g. Hoang et al., 2006; Prajogo and Sohal, 2006; Santos and Álvarez, 2007; Prajogo and Hong, 2008; Kim et al., 2012; Kafetzopoulos et al., 2015; Song and Su, 2015). Hence, we first examined separate models to justify the dimensionality of QM practices, proactive behaviours and the two types of innovation performance as first-order factors. We then used composite measures for each QM practice and examined a single measurement model with the five constructs of interest in our structural model.

\section{Dimensionality}

Accordingly, we conducted a confirmatory factor analysis (CFA) with the eleven QM practices considered as correlated first-order factors to check the dimensionality. The Lagrange multiplier test (LMTEST) was used to introduce successive modifications until the fit indices reached values within the recommended limits. Some items were deleted because they showed low reliability (ADOPHIL3 and CUSTOM1, marked with an asterisk in Appendix A). Moreover, items on Management commitment and Adopting the philosophy were found to load on a single factor, which is not surprising since both represent the leadership behind the QM initiative. For this reason, in the subsequent analyses we considered a new factor labelled Leadership, measured by the items of Management commitment and Adopting the philosophy. The goodness-of-fit values for the 
CFA model allow us to accept the dimensionality of these ten factors: S-B $\chi^{2}(618)=855.15$ $p=0.00 ; \mathrm{B}-\mathrm{BNFI}=0.910 ; \mathrm{CFI}=0.921 ; \mathrm{RMSEA}=0.047$.

Another CFA model was estimated for product and process innovation as two correlated factors. The fit values were also appropriate in this case ( $S-B \chi^{2}(23)=42.6590 ; p=0.0076$; B$\mathrm{BNFI}=0.925 ; \mathrm{CFI}=0.963$; RMSEA=0.071). Finally, the fit of the CFA for proactive behaviour confirms the unidimensionality of the factor $\left(\mathrm{S}-\mathrm{B} \chi^{2}(13)=9.7378 ; \mathrm{p}=0.7152\right.$; BBNFI=1.000; CFI=1.000; RMSEA=0.00).

\section{Reliability and Validity}

Having assessed the unidimensionality, we then tested the reliability, convergent and discriminant validity of the QM practice scales, following Santos and Álvarez (2007). Cronbach's $\alpha$ (Cronbach, 1951) and composite reliability (C.r.) (Fornell and Larcker, 1981) were used to check reliability. Table B1 in Appendix B shows that the values were greater than or close to 0.7 , therefore presenting an acceptable level of reliability.

Convergent validity was assessed with average variance extracted (AVE) (Fornell and Larcker, 1981) and by observing each item's coefficients on its underlying factor (Anderson and Gerbing, 1988) (see Table B.1 in Appendix B). Overall, evidence of convergent validity was conclusive since all the items load significantly on their respective constructs: the lowest standardised loading was 0.536 and the t-values were greater than two (which means that the value of its coefficient is greater than twice its standard error, as suggested by Anderson and Gerbing, 1988). Moreover, the AVE values show an acceptable level of average communality (AVE about or better than 0.5 ). One exception was the value for "Closer to customer" and "Open organisation", but this value could still be acceptable since it is very close to the threshold and, taking into account the satisfactory reliabilities and the other tests for convergent and discriminant validity, we decided to maintain these scales as originally developed. 
Two approaches were used to assess discriminant validity, which suggested that items assigned to one measure were not significantly loading on others. First, we performed a pair-wise test (Bagozzi and Phillips, 1982) for each pair of factors. This tests whether a CFA with two factors fits the data significantly better than a single-factor model. The scaled chi-square difference values (Satorra and Bentler, 2001) obtained for all pairs were found to be statistically significant at the $5 \%$ level, thus demonstrating discriminant validity. Second, we further tested whether Cronbach's $\alpha$ was higher than the average of its correlations with other constructs (AVISC) (Ghiselli et al., 1981), again confirming the discriminant validity of all the constructs (see Table B.1).

Following Santos and Álvarez (2007), once measures for QM practices had been analysed, we assessed a single measurement model with the five constructs used in the structural model. To this end, a CFA was tested where soft QM, hard QM, proactive behaviour, product and process innovation correlate. Given the reliability and validity of the QM measures, in order to reduce the complexity of the model we formed composite variables (Landis et al., 2000). Accordingly, hard QM and soft QM were considered as first-order factors, where the indicators are their corresponding QM practices (each one taken as a single indicator derived by averaging the items initially used). This model shows an adequate fit to the data $\left(\mathrm{S}-\mathrm{B} \chi_{(285)}^{2}=384.26 ; p=0.00 ; \quad \mathrm{B}-\mathrm{BNFI}=0.940 ; \quad \mathrm{CFI}=0.947\right.$; RMSEA $=0.046$ ) thus verifying the reliability and validity of the measurement of proactive behaviour, product and process innovation according to the aforementioned methods, as well as the unidimensionality of soft and hard QM (see Table B.2 in Appendix B). In Table B.2. the AVE values for "Soft QM" and "Product innovation" are slightly below the threshold. As explained above, we decided to maintain the items in light of the overall tests of convergent and discriminant validity. As Bollen (1989: 189) clarifies, "no one empirical test determines construct validity". Our tests on convergent and discriminant validity 
together suggest that the data, as Bagozzi and Yi (2012: 18) state, enable us to reasonably claim that "the measures converge in the proper way and yet do not relate too highly with measures of something else".

\section{Descriptive statistics of the validated measurement scales}

Table 3 shows the descriptive statistics and correlations for the elements comprising the structural model.

Table 3. Correlations and descriptive statistics

\begin{tabular}{lccccccccc}
\hline Variable & Mean & S.D. & 1 & 2 & 3 & 4 & 5 & 6 & 7 \\
\hline 1. Soft QM & 3.82 & .532 & & & & & & & \\
\hline 2. Hard QM & 3.44 & .723 & $.804^{* *}$ & & & & & & \\
\hline 3. Proactive behaviour & 3.95 & .610 & $.262^{* *}$ & $.196^{*}$ & & & & & \\
\hline 4. Product innovation & 3.46 & .584 & $.245^{* *}$ & $.298^{* *}$ & $.399^{* *}$ & & & & \\
\hline 5. Process innovation & 3.45 & .688 & $.270^{* *}$ & $.283^{* *}$ & $.439^{* *}$ & $.690^{* *}$ & & & \\
\hline 6. Size & 4.72 & 1.24 & -.007 & .026 & -.026 & .011 & -.003 & & \\
\hline 7. Sector & 0.49 & & .092 & .108 & .123 & .039 & -.105 & .108 & \\
\hline 8. I+D certification & 0.06 & & .098 & .114 & .077 & .108 & .135 & $.235^{* *}$ & -.042 \\
\hline * $p<.05 * * p<.01$ & & & & & & & & & \\
\end{tabular}

\subsection{Structural model}

We estimated a single structural model with hard and soft QM as independent variables, product and process innovation as correlated dependent variables, and proactive behaviour as the mediator. This model shows a good fit to the data $\left(\mathrm{S}-\mathrm{B} \chi^{2}(11)=11.45 ; p=0.40 ; \mathrm{B}\right.$ $\mathrm{BNFI}=0.966 ; \mathrm{CFI}=0.999 ; \mathrm{RMSEA}=0.016$ ). The values of the structural model and their statistical significance (see Table 4) support Hypothesis 1. Therefore, hard QM positively impacts the degree of product $(\beta=0.319, \mathrm{p}<.01)$ and process innovation $(\beta=0.233, \mathrm{p}<.05)$ performance. The values of the paths from soft QM to innovation performance do not allow us to support Hypothesis 2, since soft QM has no direct effect on either product innovation 
or process innovation.

Table 4. Parameter estimates, standard errors and t-test for the structural model

\begin{tabular}{|c|c|c|c|}
\hline Estimated Relationships & $\begin{array}{c}\text { Standardised } \\
\text { Structural } \\
\text { Coefficients }\end{array}$ & S.E. & t-test \\
\hline \multicolumn{4}{|l|}{ DIRECT EFFECTS } \\
\hline Hard QM $\rightarrow$ product innovation performance $(\mathrm{H} 1)$ & $0.319 * *$ & 0.096 & 2.67 \\
\hline Hard QM $\rightarrow$ process innovation performance $(\mathrm{H} 1)$ & $0.233^{*}$ & 0.098 & 2.28 \\
\hline Soft QM $\rightarrow$ product innovation performance $(\mathrm{H} 2)$ & -0.111 & 0.135 & -0.90 \\
\hline Soft $\mathrm{QM} \rightarrow$ process innovation performance $(\mathrm{H} 2)$ & -0.020 & 0.131 & -0.19 \\
\hline Hard QM $\rightarrow$ proactive behaviour $(\mathrm{H} 3)$ & -0.050 & 0.122 & -0.34 \\
\hline Soft QM $\rightarrow$ proactive behaviour $(\mathrm{H} 4)$ & $0.305^{*}$ & 0.161 & 2.16 \\
\hline $\begin{array}{l}\text { Proactive behaviour } \rightarrow \text { product innovation } \\
\text { performance }(\mathrm{H} 5)\end{array}$ & $0.366^{* *}$ & 0.068 & 5.19 \\
\hline $\begin{array}{l}\text { Proactive behaviour } \rightarrow \text { process innovation } \\
\text { performance }(\mathrm{H} 5)\end{array}$ & $0.409 * *$ & 0.082 & 5.63 \\
\hline Size $\rightarrow$ product innovation performance & -0.009 & 0.029 & -0.141 \\
\hline Size $\rightarrow$ process innovation performance & -0.007 & 0.033 & -0.122 \\
\hline Sector $\rightarrow$ product innovation performance & -0.026 & 0.079 & -0.379 \\
\hline Sector $\rightarrow$ process innovation performance & $-0.175 * *$ & 0.090 & -2.69 \\
\hline $\begin{array}{l}\text { I+D certification } \rightarrow \text { product innovation } \\
\text { performance }\end{array}$ & 0.057 & 0.184 & 0.77 \\
\hline $\begin{array}{l}\text { I+D certification } \rightarrow \text { process innovation } \\
\text { performance }\end{array}$ & 0.075 & 0.196 & 1.11 \\
\hline \multicolumn{4}{|l|}{ INDIRECT EFFECTS (H6) } \\
\hline Soft QM $\rightarrow$ product innovation performance & $0.111^{*}$ & 0.055 & 2.19 \\
\hline Soft QM $\rightarrow$ process innovation performance & $0.125^{*}$ & 0.071 & 2.25 \\
\hline Hard QM $\rightarrow$ product innovation performance & -0.018 & 0.043 & -0.34 \\
\hline Hard QM $\rightarrow$ process innovation performance & -0.020 & 0.057 & -0.34 \\
\hline \multicolumn{4}{|l|}{ TOTAL EFFECT } \\
\hline Soft QM $\rightarrow$ product innovation performance & 0.000 & 0.153 & 0.02 \\
\hline Soft QM $\rightarrow$ process innovation performance & 0.104 & 0.156 & 0.86 \\
\hline Hard QM $\rightarrow$ product innovation performance & $0.301^{*}$ & 0.109 & 2.22 \\
\hline Hard QM $\rightarrow$ process innovation performance & $0.213+$ & 0.118 & 1.73 \\
\hline
\end{tabular}

Hypothesis 3 was not supported since the values failed to achieve statistical significance; we therefore found no relationship between hard QM and proactive behaviour. Nevertheless, we did find a significant and positive relationship between soft QM and proactive behaviour $(\beta=0.305, p<.05)$, thus supporting Hypothesis 4 . The results also confirmed the existence of the link between proactive behaviour and innovation performance (Hypothesis 5), since the former impacts on both product innovation $(\beta=0.366$, $p<.001)$ and process innovation $(\beta=0.409, p<.001)$.

The decomposition of effects shows an indirect effect of soft QM on innovation 
performance through proactive behaviour, since significant and positive values were found for product innovation $(\beta=0.111, p<.05)$ and for process innovation $(\beta=0.125, p<.05)$. In order to better justify this indirect effect we conducted a comparison between our structural model and a nested competing model where the indirect effects through proactive behaviour do not exist. Following Hair et al. (2010), the nested models were compared based on a $\chi^{2}$ difference statistic. The statistically significant $(\mathrm{p}=0.002)$ difference in $\chi^{2}$ $\left(\Delta \chi^{2}=12.39\right.$ with $\Delta \mathrm{df}=2$ ) denoted that our structural model fits the data better than the competing model. Furthermore, to test whether the mediating effect is partial or total we analysed another nested competing model following Holmbeck (1997). This procedure is well established in the literature (e.g., Prajogo and Ahmed, 2006) and enables a comparison to be made between our structural model and another one where the direct effects between soft $\mathrm{QM}$ and product and process innovation is constrained to zero. A $\chi^{2}$ difference test between the two models $\left(\Delta \chi^{2}=1.14\right.$ with $\left.\Delta \mathrm{df}=2\right)$ shows that it was non-statistically significant $(p=0.566)$ and suggests that deleting the direct paths does not make the model inferior. This comparison thus confirms a full mediation of proactive behaviour in the relationship between soft QM and innovation performance. Hence, we did not find a significant direct association between soft QM and innovation performance, but an indirect pathway via proactive behaviour.

This indirect effect was not found in the case of hard QM, indicating that its influence on innovation performance is only direct. Therefore, proactive behaviour acts solely as a full mediator in the soft QM-innovation performance link, partially confirming Hypothesis 6. With regard to control variables, the size of the organisation does not affect innovation performance, neither does the certification of technological management system, which is consistent with previous studies (e.g. Perdomo et al., 2009b; Camisón and Puig, 2016) and suggests that small size should not be a drawback for innovation and that it transcends the 
use of norms and standards. However, the sector has an impact on the level of process innovation, since the chemical sector is associated with lower levels of this type of innovation performance $(\beta=-0.175, p<.01)$.

\section{Discussion}

\subsection{Main findings}

An initial interesting finding from this study concerns the different way that QM dimensions relate with innovation performance. While hard QM exhibits a direct impact, the relationship with soft QM is indirect, channelled via proactive behaviour. According to our findings, hard QM significantly promotes both product and process innovation. In line with Kim et al.'s (2012) results, our study reveals the role of techniques and methods like process management as determinant for innovation. As Zeng et al. (2015) explain, hard QM implies the use of quality techniques, which support the establishment of order and control, necessary to learn how to improve and generate the conditions for innovating. Standardisation and reducing the variation that could be derived from hard QM practices do not seem to strangle innovation and do not prevent employees from trying new techniques or new ideas. Our results support the view that continuous improvement is instrumental for innovation since it boosts change and creativity (Prajogo and Sohal, 2001; Zeng et al., 2017). In contrast, we found no support for the alternative view that the effect of core QM practices (hard QM) on innovation is insignificant (e.g. Song and Su, 2015), nor for Benner and Tushman's (2003) view that process management generates inertia, resistance to change and, in turn, may inhibit innovation.

Regarding soft QM, some previous contributions (e.g. Prajogo and Sohal, 2004; Feng et al., 2006) concluded that only this dimension can lead to innovation. However, contrary to their findings, it can foster innovation but only indirectly by way of promoting proactive 
behaviours. The non-significant direct effect supports the argument that in the absence of proactive behaviour, soft QM does not enable innovation performance. Soft QM needs to encourage an atmosphere of trust that nurtures employees' personal initiative. It needs to create the infrastructure needed to give employees the opportunity to channel their initiative in the creation of new ideas. Our findings tally with the conclusions by scholars such as Silva et al. (2014) or Zeng et al. $(2015,2017)$ regarding the infrastructure role of soft QM practices. Soft QM has no direct effect on performance but it is the way to create the environment necessary for other practices to influence performance. For instance, practices related to human resource management, such as empowerment or teamwork, may enable employees to use other QM tools necessary to develop new ideas. These conclusions advise modelling the relationship between QM practices and performance in the sequence from soft to hard QM and then to performance, as suggested by Zeng et al. (2015).

These findings imply that considering QM as a set of practices integrated in a unidimensional scale to analyse the QM-innovation link is not a suitable approach, since soft and hard QM dimensions may play different roles. Hence, this unidimensional approach may give rise to inconsistent results, and scholars should adopt a multidimensional view of QM to study innovation in the context of a QM initiative.

Second, as the scope of product and process innovation adopted in this study covers radical innovation characteristics, our findings show that both dimensions of QM do not necessarily preclude the newness of technological aspects or being an early entrant in the market. Hence, the results obtained are in line with Sethi and Sethi (2009) since QM does not adversely affect product novelty, and Kim et al. (2012) who found QM to be beneficial to organisations struggling to create radical innovation. In contrast, the emphasis on reducing variation does not seem to trap employees in their current methods and hinder the generation of innovative ideas, as some authors have suggested (e.g. Benner and Tushman, 
2003; Song and $\mathrm{Su}, 2015)$. Indeed, as Gil and Moreno (2013) conclude, QM may be a foundation for more radical innovation since it is not an obstacle to increase the degree of novelty in product and process innovation.

Third, as explained above, the soft dimension of QM includes many of the HPWP and, as a consequence, it contributes to shaping the work context by fostering proactivity among the workforce. This is a relevant result, since many of the studies that analyse the antecedents of proactive behaviours focus on individual characteristics such as intrinsic motivation, goal orientation or organisational tenure on proactivity (see, for example, Frese and Fay, 2001; Sonnentag, 2003; Belschak and Den Hartog, 2010). However, few studies have examined the role of contextual variables of the organisation as enablers of proactive behaviour (Batistič et al., 2016). Our results contribute to this literature by demonstrating how companies that effectively implement the social features of QM would encourage proactivity among their employees as a consequence. However, contrary to what we expected, we did not find a significant effect between the hard dimension of QM and proactivity. In our study, hard QM, which emphasises providing information to employees and controlling processes in the organisation, does not directly influence employee proactivity. The explanation for this finding could be that because proactive behaviours are motivation-driven, the literature emphasises human resource management practices as the significant variables that can impact proactive behaviour by increasing employee motivation, abilities and opportunity to perform (Maden, 2015; Beltrán et al., 2017). According to this literature, hard QM practices may not be able to provide the motivational potential to promote proactive behaviours.

Fourth, our results support the proposition that proactive behaviour has a positive influence on innovation performance. These results are broadly in line with previous studies showing that proactivity orientates employees to anticipate change and innovation (Crant, 2000; 
Grant and Ashford, 2008; Anderson et al., 2014). Benefits from proactive behaviour become particularly relevant for firms operating in dynamic industries where technology and customer preferences change rapidly (Unsworth and Parker, 2003). Some scholars point to the scant research on the link between proactivity and innovation, two traditionally separate research streams and, in addition, most empirical studies looking at this relationship focus mainly on innovation at the individual level (Unsworth and Parker, 2003; Fischer et al., 2014). While most studies have explored the top-down implementation of innovative projects, there is little analysis of employee initiatives in promoting innovation within companies (Rigtering and Weitzel, 2013); studies taking a focus on employee behaviour and stimulation to lead innovation are therefore needed. The results of the present study contribute to this line of research.

In addition, QM has been shown as beneficial in the context of high-tech sectors, where innovation is paramount, confirming previous conclusions by studies conducted in the same kind of sectors (e.g. Perdomo et al., 2009a; Hung et al., 2011). In the same vein, the findings from this study support the view of previous authors such as Chatterji and Davidson (2001) and Kumar and Boyle (2001), who point out that QM can be beneficial in innovative environments (such as high-tech sectors) since it helps to focus on the needs and expectations of clients, and to understand the organisation as a set of processes, which helps to improve communication channels in the organisation and makes them more receptive to measurement systems.

\subsection{Managerial implications}

The findings derived from this research assist managers to conceive QM initiatives as possible enablers of innovations and justify investments in QM. They need to be aware that QM is not a drawback for innovation and that in innovative environments it can foster product and process innovation. In other words, managers should not abandon QM when 
they want to promote innovation. Moreover, managers should be aware of the different roles that soft and hard QM practices can have on innovation performance. Soft QM should be developed as a way to create the necessary infrastructure allowing employees to take the initiative to handle new ideas. Interorganisational relationships with customers and suppliers as well as QM practices linked with human resource management practices, such as training, empowerment or teamwork, are necessary to promote proactivity and, in turn, innovation. These practices will probably not have a direct effect on performance, but they will help create the atmosphere for implementing other more technical practices, such as process management and measurement, which will help to generate new ideas for product and process innovation. Moreover, managers need to be aware of the importance of these kinds of practices to promote proactive behaviour among employees, which has been observed to be important for innovation.

\subsection{Limitations and future line of research}

A number of limitations need to be acknowledged. First, although our measure of product and process innovation captures the idea of newness and radicalness, dichotomising between radical and incremental innovation could be considered in future research to help settle the controversy over the consequences of QM for innovation. Taking into account that several arguments supporting the lack of a relationship between QM and innovation often refer to radical innovation (Silva et al, 2014), it would be interesting to take a multidimensional approach to QM to explore the effects of hard and soft QM on these different types of innovation. Second, we used quantitative measurement to evaluate QM, proactive behaviour and innovation. It would be worth leading some case studies in the organisations analysed to complement the survey. Third, although our sample is sufficient to test our structural model, we used submodels with related constructs to examine the measurement models due to sample size restrictions. Future research should attempt to test 
the full measurement model in a survey with more data. Fourth, the data used in the study is derived from two high-tech sectors in Spain and firms that are familiar with QM because they are ISO 9001 certified. At the current time, the findings reflect the reality of the two sectors considered and cannot be generalised to all high-tech sectors, which is an avenue for future research. New studies could usefully test the proposed relationships in both certified and noncertified organisations. Finally, further contributions should continue analysing the role of other variables in the QM-innovation link, adopting a contingent approach. Exploring moderating variables such as degree of formalisation will shed light on how standardisation might be suitable for improving innovation efforts in quality driven organisations.

\section{Conclusion}

This study contributes to the knowledge on the relationship between QM and innovation performance by considering the dimensionality of $\mathrm{QM}$ and incorporating proactive behaviour as a mediator variable in this relationship. The results derived from the empirical study encourage adopting QM practices in order to sustain innovation performance. Both hard and soft QM contribute to innovation, although in different ways. While hard QM directly contributes to product and process innovation thanks to the provision of routines to detect areas of improvement and eliminate non-value-added processes, soft QM provides the necessary infrastructure for employees to behave proactively and be able to participate in the innovation process by providing new ideas. In addition, this research has highlighted the role of proactive employees in innovation. This paper has, therefore, identified the innovation performance drivers from a QM initiative that could guide future decisions. 


\section{Appendix A. Measurement items}

\section{Variables}

\section{QUALITY MANAGEMENT}

Question: Please indicate the level of implementation of the features given below

Scale: $1=$ "implementation not yet begun" and 5="implementation highly advanced"

Measurement instrument used previously by Powell (1995), Gómez and Verdú (2005), Sharma (2006), Gadenne and

Sharma (2009), Carmona et al. (2016)

\section{Benchmarking}

BENCH1. An active competitive benchmarking programme

$\mathrm{BENCH} 2$. Researching best practices in other organisations

$\mathrm{BENCH}$. Visiting other organisations to investigate best practices first hand

\section{Zero-defects mentality}

ZERODEF1. An announced goal of zero-defects

ZERODEF2. A programme for continuous reduction in defects

ZERODEF3. A plan to reduce rework drastically

\section{Process improvement}

PROCIMPR1. A programme to reduce order-processing cycle

PROCIMPR2. A programme to reduce new product or service development cycle times

PROCIMPR3. A programme to reduce overall product or service delivery cycle times

PROCIMPR4. A programme to reduce paperwork

PROCIMPR5. A programme to find wasted time and costs in all internal processes

\section{Measurement}

MEASUR1. Measurement of quality performance in all areas

MEASUR2. Charts and graphs to measure and monitor quality

MEASUR3. Statistical methods to measure and monitor quality

MEASUR4. Employee training in statistical methods for measuring quality

\section{Management commitment}

MANAGCOM1 A top executive decision to commit fully to a quality initiative

MANAGCOM2. Top managers actively championing our quality initiative

MANAGCOM3. Managers actively communicating a quality commitment to employees

\section{Adopting the philosophy}

ADOPHIL1. Quality principles included in our mission statement

ADOPHIL2. An overall theme based on our quality initiative

ADOPHIL3. Entering an quality award competition*

\section{Closer to customer}

CUSTOM1. Increasing the organisation's direct personal contacts with customers*

CUSTOM2. Actively seeking customer inputs to determine their requirements

CUSTOM3. Using customer requirements as the basis for quality

CUSTOM4. Involving customers in product or service design

\section{Closer to supplier}

SUPPLI1. Working more closely with suppliers

SUPPLI2. Requiring suppliers to meet stricter quality specifications

SUPPLI3. Requiring suppliers to adopt a quality initiative

\section{Increased training}

TRAIN1. Management training in quality principles

TRAIN2. Employee training in quality principles

TRAIN3. Employee training in problem-solving skills

TRAIN 4. Employee training in teamwork

\section{Open organisation}

OPENORG1. A more open, trusting organisational culture

OPENORG2. Less bureaucracy 
OPENORG3. Frequent use of cross-departmental teams

OPENORG4. Use of empowered work teams

Employee empowerment

EMPOW1. Increased employee involvement in design and planning

EMPOW2. A more active employee suggestion system

EMPOW3. Increased employee autonomy in decision-making

EMPOW4. Increased employee interaction with customers and suppliers

\section{PROACTIVE BEHAVIOUR}

Question: Please indicate the number that best reflects your level of agreement with the following questions regarding the behaviour of employees in the area of product/service development

Scale: $1=$ "strongly disagree" and 5="strongly agree"

Measurement instrument used previously by Baer and Frese (2003), adapted from Frese et al. (1997)

PROAC1. They tackle problems actively

PROAC2. Whenever something goes wrong, they search for a solution immediately

PROAC3. Whenever there is a chance to get actively involved, they take it

PROAC4. They take the initiative immediately even when others don't

PROAC5. They use opportunities quickly in order to attain their goals

PROAC6. Usually they do more than they are asked to do

PROAC7. They are particularly good at carrying out ideas

\section{INNOVATION PERFORMANCE}

Question: Please indicate the number that best reflects how your organisation has been doing so far relative to your main competitors

Scale: $1=$ "worst in industry" and 5="best in industry"

Measurement instrument used previously by Prajogo and Sohal (2006), Hung et al. (2011), Ooi et al. (2012),

Kafetzopoulos et al. (2015)

\section{Product innovation}

PRODIN1. The level of newness (novelty) of our firm's new products.

PRODIN2. The use of latest technological innovations in our new products

PRODIN3. The speed of our new product development

PRODIN4. The number of new products our firm has introduced to the market

PRODIN5. The number of our new products that are first-to-market (early market entrants)

\section{Process innovation}

PROCIN1. The technological competitiveness of our company

PROCIN2. The speed with which we adopt the latest technological innovations in our processes

PROCIN3. The updated-ness or novelty of the technology used in our processes

PROCIN4. The rate of change in our processes, techniques and technology

\section{Appendix B. Properties of the measurement instruments}

Table B1. Reliability, convergent and discriminant validity of QM practices

\begin{tabular}{|l|c|c|c|c|c|c|c|}
\hline \multicolumn{1}{|c|}{ Variables } & Loadings & S.E. & t-test & Cronbach's $\alpha$ & C.r. & AVE & AVISC \\
\hline Benchmarking & & & & 0.84 & 0.85 & 0.66 & 0.44 \\
BENCH1 & 0.802 & 0.061 & 5.77 & & & & \\
BENCH2 & 0.846 & 0.035 & 7.41 & & & & \\
BENCH3 & 0.784 & 0.076 & 5.95 & & & & \\
& & & & 0.83 & 0.63 & 0.51 \\
Zero-defects mentality & 0.694 & 0.095 & 6.21 & & & & \\
ZERODEF1 & 0.816 & 0.059 & 5.79 & & & & \\
ZERODEF2 & 0.859 & 0.049 & 6.13 & & & \\
ZERODEF3 & & & & & & \\
\hline
\end{tabular}




\begin{tabular}{|c|c|c|c|c|c|c|c|}
\hline $\begin{array}{l}\text { Process improvement } \\
\text { PROCIMPR1 } \\
\text { PROCIMPR2 } \\
\text { PROCIMPR3 } \\
\text { PROCIMPR4 } \\
\text { PROCIMPR5 }\end{array}$ & $\begin{array}{l}0.773 \\
0.809 \\
0.851 \\
0.702 \\
0.809\end{array}$ & $\begin{array}{l}0.092 \\
0.084 \\
0.045 \\
0.092 \\
0.075\end{array}$ & $\begin{array}{l}5.81 \\
5.24 \\
6.56 \\
6.87 \\
6.12\end{array}$ & 0.89 & 0.89 & 0.63 & 0.52 \\
\hline $\begin{array}{l}\text { Measurement } \\
\text { MEASUR1 } \\
\text { MEASUR2 } \\
\text { MEASUR3 } \\
\text { MEASUR4 }\end{array}$ & $\begin{array}{l}0.716 \\
0.793 \\
0.841 \\
0.678\end{array}$ & $\begin{array}{l}0.070 \\
0.065 \\
0.073 \\
0.093\end{array}$ & $\begin{array}{l}6.47 \\
5.74 \\
4.71 \\
8.12\end{array}$ & 0.83 & 0.84 & 0.58 & 0.47 \\
\hline $\begin{array}{l}\text { Leadership } \\
\text { MANAGCOM1 } \\
\text { MANAGCOM2 } \\
\text { MANAGCOM3 } \\
\text { ADOPHILO1 } \\
\text { ADOPHILO2 }\end{array}$ & $\begin{array}{l}0.901 \\
0.926 \\
0.856 \\
0.695 \\
0.657\end{array}$ & $\begin{array}{l}0.018 \\
0.019 \\
0.029 \\
0.027 \\
0.028\end{array}$ & $\begin{array}{l}4.34 \\
4.05 \\
6.59 \\
7.37 \\
8.72\end{array}$ & 0.90 & 0.91 & 0.66 & 0.41 \\
\hline $\begin{array}{l}\text { Closer to customer } \\
\text { CUSTOM2 } \\
\text { CUSTOM3 } \\
\text { CUSTOM4 }\end{array}$ & $\begin{array}{l}0.646 \\
0.744 \\
0.588\end{array}$ & $\begin{array}{l}0.050 \\
0.048 \\
0.093\end{array}$ & $\begin{array}{l}6.65 \\
5.04 \\
6.09\end{array}$ & 0.69 & 0.70 & 0.45 & 0.36 \\
\hline $\begin{array}{l}\text { Closer to supplier } \\
\text { SUPPLI1 } \\
\text { SUPPLI2 } \\
\text { SUPPLI3 }\end{array}$ & $\begin{array}{l}0.671 \\
0.823 \\
0.776\end{array}$ & $\begin{array}{l}0.082 \\
0.059 \\
0.081\end{array}$ & $\begin{array}{l}5.91 \\
5.03 \\
5.66\end{array}$ & 0.79 & 0.80 & 0.58 & 0.41 \\
\hline $\begin{array}{l}\text { Increased training } \\
\text { TRAIN1 } \\
\text { TRAIN2 } \\
\text { TRAIN3 } \\
\text { TRAIN4 }\end{array}$ & $\begin{array}{l}0.798 \\
0.756 \\
0.804 \\
0.835\end{array}$ & $\begin{array}{l}0.062 \\
0.085 \\
0.083 \\
0.053\end{array}$ & $\begin{array}{l}4.99 \\
6.05 \\
5.03 \\
6.31\end{array}$ & 0.88 & 0.88 & 0.64 & 0.46 \\
\hline $\begin{array}{l}\text { Open organisation } \\
\text { OPENORG1 } \\
\text { OPENORG2 } \\
\text { OPENORG3 } \\
\text { OPENORG4 }\end{array}$ & $\begin{array}{l}0.536 \\
0.611 \\
0.646 \\
0.844\end{array}$ & $\begin{array}{l}0.075 \\
0.100 \\
0.107 \\
0.115\end{array}$ & $\begin{array}{l}6.36 \\
5.30 \\
5.80 \\
7.23\end{array}$ & 0.72 & 0.76 & 0.45 & 0.51 \\
\hline $\begin{array}{l}\text { Employee empowerment } \\
\text { EMPOW1 } \\
\text { EMPOW2 } \\
\text { EMPOW3 } \\
\text { EMPOW4 }\end{array}$ & $\begin{array}{l}0.682 \\
0.687 \\
0.837 \\
0.636\end{array}$ & $\begin{array}{l}0.063 \\
0.084 \\
0.046 \\
0.083\end{array}$ & $\begin{array}{l}8.43 \\
7.65 \\
5.43 \\
6.74\end{array}$ & 0.79 & 0.80 & 0.51 & 0.47 \\
\hline
\end{tabular}

Table B2. Reliability, convergent and discriminant validity for the single measurement model

\begin{tabular}{|l|c|c|c|c|c|c|c|}
\hline \multicolumn{1}{|c|}{ Variables } & Loadings & S.E. & t-test & Cronbach's $\boldsymbol{\alpha}$ & C.r. & AVE & AVISC \\
\hline Hard QM & & & & 0.92 & 0.84 & 0.56 & 0.39 \\
-Benchmarking & 0.564 & 0.070 & 7.08 & & & & \\
-Zero-defects mentality & 0.818 & 0.063 & 11.77 & & & & \\
-Process improvement \\
-Measurement
\end{tabular}




\begin{tabular}{|c|c|c|c|c|c|c|c|}
\hline $\begin{array}{l}\text {-Closer to Customer } \\
\text {-Closer to Supplier } \\
\text {-Increased training } \\
\text {-Open organisation } \\
\text {-Employee empowerment }\end{array}$ & $\begin{array}{l}0.511 \\
0.544 \\
0.682 \\
0.819 \\
0.753\end{array}$ & $\begin{array}{l}0.054 \\
0.060 \\
0.061 \\
0.042 \\
0.048\end{array}$ & $\begin{array}{c}6.08 \\
7.42 \\
10.09 \\
13.53 \\
12.50\end{array}$ & & & & \\
\hline $\begin{array}{l}\text { Proactive behaviour } \\
\text { PROAC1 } \\
\text { PROAC2 } \\
\text { PROAC3 } \\
\text { PROAC4 } \\
\text { PROAC5 } \\
\text { PROAC6 } \\
\text { PROAC7 }\end{array}$ & $\begin{array}{l}0.712 \\
0.711 \\
0.892 \\
0.862 \\
0.823 \\
0.647 \\
0.749\end{array}$ & $\begin{array}{l}0.045 \\
0.057 \\
0.054 \\
0.052 \\
0.064 \\
0.055 \\
0.060\end{array}$ & $\begin{array}{c}10.27 \\
8.32 \\
12.24 \\
13.36 \\
9.64 \\
9.75 \\
10.12\end{array}$ & 0.91 & 0.91 & 0.60 & 0.32 \\
\hline $\begin{array}{l}\text { Product innovation } \\
\text { PRODIN1 } \\
\text { PRODIN2 } \\
\text { PRODIN3 } \\
\text { PRODIN4 } \\
\text { PRODIN5 }\end{array}$ & $\begin{array}{l}0.744 \\
0.731 \\
0.558 \\
0.622 \\
0.596\end{array}$ & $\begin{array}{l}0.045 \\
0.059 \\
0.072 \\
0.063 \\
0.071\end{array}$ & $\begin{array}{l}10.81 \\
9.56 \\
6.29 \\
8.20 \\
7.37\end{array}$ & 0.79 & 0.79 & 0.45 & 0.40 \\
\hline $\begin{array}{l}\text { Process innovation } \\
\text { PROCIN1 } \\
\text { PROCIN2 } \\
\text { PROCIN3 } \\
\text { PROCIN4 }\end{array}$ & $\begin{array}{l}0.724 \\
0.790 \\
0.833 \\
0.819\end{array}$ & $\begin{array}{l}0.057 \\
0.059 \\
0.058 \\
0.058\end{array}$ & $\begin{array}{l}10.55 \\
11.39 \\
11.25 \\
11.37\end{array}$ & 0.86 & 0.87 & 0.63 & 0.42 \\
\hline
\end{tabular}

\section{References}

Adhikari, D.R. (2010), "Human resource development (HRD) for performance management", International Journal of Productivity and Performance Management, Vol.59, No. 4, pp.306-324.

Ahire, S.L., and Devaraj, S. (2001), "An empirical comparison of statistical construct validation approaches", IEEE Transactions on Engineering Management, Vol.48, No.3, pp.319-329.

Anderson, J.C. and Gerbing, D.W, (1988), "Structural equation modeling in practice: a review and recommended two-step approach", Psychological Bulletin, Vol.103, No.3, pp.411-423.

Anderson, N., Potočnik, K., and Zhou, J. (2014), "Innovation and Creativity in Organizations A State-of-theScience Review, Prospective Commentary, and Guiding Framework", Journal of Management, Vol.40, No.5, pp.1297-1333.

Armstrong, J.S., and Overton, T.S. (1977), "Estimating nonresponse bias in mail surveys", Journal of Marketing Research, No.14, pp.396-402.

Axtell, C.M., Holman, D.J., Unsworth, K.L., Wall, T.D., Waterson, P.E., and Hurrington, E. (2000), "Shopfloor innovation: Facilitating the suggestion and implementation of ideas", Journal of Occupational and Organizational Psychology, Vol.73, No.3, pp.265-285.

Baer, M., and Frese, M. (2003), "Innovation is not enough: climates for initiative and psychological safety, process innovations, and firm performance”, Journal of Organizational Behavior, Vol.24, pp.45-68.

Bagozzi, R.P. and Phillips, L.W. (1982), "Representing and testing organizational theories: a holistic construal", Administrative Science Quarterly, Vol.27, pp.459-489.

Bagozzi, R.P., and Yi, Y. (2012), "Specification, evaluation, and interpretation of structural equation models", Journal of the Academy of Marketing Science, Vol.40, No.1, pp.8-34.

Bateman, T.S. and Crant, J.M. (1993), "The proactive component of organizational behavior: A measure and correlates", Journal of Organizational Behavior, Vol.14, No.2, pp.103-118.

Batistič, S., Černe, M., Kaše, R., and Zupic, I. (2016), "The role of organizational context in fostering employee proactive behavior: The interplay between HR system configurations and relational climates", European Management Journal, Vol.34, No.5, pp.579-588.

Bauer, M., and Leker, J. (2013), "Exploration and exploitation in product and process innovation in the chemical industry", $R \& D$ Management, Vol.43, No.3, pp.196-212.

Belschak, F.D. and Den Hartog, D.N. (2010), "Pro-self, prosocial, and pro-organizational foci of proactive behaviour: Differential antecedents and consequences", Journal of Occupational and Organizational Psychology, Vol.83, No.2, pp.475-498. 
Beltrán, I., Bou, J.C., Roca, V., and Escrig, A.B. (2017), “The relationship between high performance work systems and employee proactive behaviour: role breadth self-efficacy and flexible role orientation as mediating mechanisms", Human Resource Management Journal. doi: 10.1111/1748-8583.12145

Benner, M.J. and Tushman, M.L. (2003), "Exploitation, exploration, and process management: The productivity dilemma revisited", Academy of management review, Vol.28, No.2, pp.238-256.

Bentler, P.M. (2006), EQS 6 Structural Equations Program Manual, Multivariate Software, Inc., Encino (California).

Bentler, P.M., and Chou, C.P. (1987), "Practical issues in structural modelling", Sociological Methods \& Research, Vol.16, No.1, pp. 78-117.

Blau, P.M. (1964), Exchange and power in social life, Wiley, New York.

Bollen, K.A. (1989), Structural Equations with Latent Variables, John Wiley \& Sons, New York.

Bou, J.C., Escrig, A.B., Roca, V., and Beltrán, I. (2009), "An empirical assessment of the EFQM excellence model: evaluation as a TQM framework relative to the MBNQA model", Journal of Operations Management, Vol.27, No.1, pp.1-22

Brannick, M.T., Chan, D., Conway, J.M., Lance, C.E., and Spector, P.E. (2010), "What is method variance and how can we cope with it? A panel discussion", Organizational Research Methods, Vol.13, No.3, pp.407-420.

Camisón, C. and Puig, A. (2016), “Are quality management practices enough to improve process innovation?", International Journal of Production Research, Vol.54, No.10, pp.2875-2894.

Carmona, F.J., Leal, A.G., Vázquez, A.E., Leal, A.L., and Eldridge, S. (2016), "TQM and business success: Do all the TQM drivers have the same relevance? An empirical study in Spanish firms", International Journal of Quality \& Reliability Management, Vol.33, No.3, pp.361-379.

Chatterji, D. and Davidson, J.M. (2001), "Examining TQM's legacies for R\&D", Research Technology Management, Vol.44, No.1, pp.10-12.

Combs, J., Liu, Y., Hall, A., and Ketchen, D. (2006), "How much do high-performance work practices matter? A meta-analysis of their effects on organizational performance", Personnel Psychology, Vol.59, No.3, pp.501-528.

Crant, J.M. (2000), "Proactive Behavior in Organizations", Journal of Management, Vol.26, No.3, pp.435462.

Cronbach, L.J. (1951), “Coefficient alpha and the internal structure of tests”, Psychometrika, Vol.16, pp.297334.

Damanpour, F. (1991), "Organizational innovation: a meta-analysis of effects of determinants and moderators", Academy of Management Journal, Vol.34, pp.555-90.

Damanpour, F. (1992), “Organizational size and innovation”, Organization studies, Vol.13, No.3, pp.375-402.

Ebrahimi, M. and Sadeghi, M. (2013), "Quality management and performance: An annotated review", International Journal of Production Research, Vol.51, No.18, pp.5625-5643.

Ehrhart, M.G. (2004), "Leadership and procedural justice climate as antecedents of unit- level organizational citizenship behavior", Personnel Psychology, Vol.57, No.1, pp.61-94.

Erkutlu, H., and Chafra, J. (2012), "The impact of team empowerment on proactivity. The moderating roles of leader's emotional intelligence and proactive personality", Journal of Health Organization and Management, Vol.26, No.5, pp.560-577.

Escrig, A.B., Bou, J.C., Roca, V., and Beltrán, I. (2012), “Does quality management drive labour flexibility?”, Total Quality Management \& Business Excellence, Vol.23, No.2, pp.159-176.

Ettlie, J.E. (1990), “What makes a manufacturing firm innovative?”, The Executive, Vol.4, No.4, pp.7-20.

Ettlie, J.E., Bridges, W.P., and O'keefe, R.D. (1984), "Organization strategy and structural differences for radical versus incremental innovation”, Management Science, Vol.30, No.6, pp.682-695.

Feng, J., Prajogo, D.I., Chuan Tan, K., and Sohal, A.S. (2006), "The impact of TQM practices on performance: A comparative study between Australian and Singaporean organizations", European Journal of Innovation Management, Vol.9, No.3, pp.269-278.

Fischer, S., Frese, M., Mertins, J.C., Hardt, J.V., Flock, T., Schauder, J., Schmitz, M., and Wiegel, J. (2014), "Climate for personal initiative and radical and incremental innovation in firms: A validation study", Journal of Enterprising Culture, Vol.22, No.1, pp.91-109.

Flynn, B.B. (1994), "The relationship between quality management practices, infrastructure and fast product innovation”, Benchmarking for Quality Management \& Technology, Vol.1, No.1, pp.48-64.

Flynn, B.B., Schroeder, R.G., and Sakakibara, S., (1995), "The impact of quality management practices on performance and competitive advantage", Decision Sciences, Vol.26, No.5, pp.659-691.

Fornell, C. and Larcker, D.F. (1981), "Evaluating structural equation models with unobservable variables and measurement error", Journal of Marketing Research, Vol.18, No.1, pp.39-50. 
Frese, M. and Fay, D. (2001), "Personal Initiative: An Active Performance Concept for Work in the 21st Century", in Staw, B.M. and Sutton, R.I. (Eds.), Research in Organizational Behavior, Elsevier Science, Amsterdam, pp.133-187.

Frese, M., Fay, D., Hilburger, T., Leng, K., and Tag, A. (1997), "The concept of personal initiative: Operationalization, reliability and validity in two German samples", Journal of Organizational and Occupational Psychology, Vol.70, No.2, pp.139-161.

Frese, M., Kring, W., Soose, A., and Zempel, J. (1996), "Personal Initiative at work: Differences between East and West Germany", Academy of Management Journal, Vol.39, No.1, pp.37-63.

Fritz, C. and Sonnentag, S. (2009), "Antecedents of Day-Level Proactive Behavior: A Look at Job Stressors and Positive Affect During the Workday?", Journal of Management, Vol.35, No.1, pp.94-111.

Fuller, J.B., Marler, L.E., and Hester, K. (2006), "Promoting felt responsibility for constructive change and proactive behavior: Exploring aspects of an elaborated model of work design", Journal of Organizational Behavior, Vol.27, No.8, pp.1089-1120.

Gadenne, D. and Sharma, B. (2009), "An investigation of the hard and soft quality management factors of Australian SMEs and their association with firm performance", International Journal of Quality \& Reliability Management, Vol.26, No.9, pp.865-880.

Ghauri, P., Gronhaug, K., and Kristianslund, I. (1995), Research methods in business studies: a practical guide, Prentice Hall, London.

Ghiselli, E.E., Campbell, J.P. and Zedeck, S. (1981), Measurement Theory for Behavioral Sciences. Freeman, San Francisco, CA.

Gil, M. and Moreno, M. (2013), "Driving human resources towards quality and innovation in a highly competitive environment", International Journal of Manpower, Vol.34, No.8, pp.839-860.

Gómez, J.M., and Verdú, A.J. (2005), "TQM, structural and strategic flexibility and performance: an empirical research study", Total Quality Management \& Business Excellence, Vol.16, No.7, pp.841-860.

Grant, A.M. and Ashford, S. J. (2008), "The dynamics of proactivity at work", Research in Organizational Behavior, Vol.28, pp.3-34.

Griffin, M.A., Neal, A., and Parker, S.K. (2007), "A new model of work role performance: Positive behavior in uncertain and interdependent contexts", Academy of Management Journal, Vol.50, No.2, pp.327-347.

Hackman, J.R. and Wageman, R. (1995), "Total quality management: empirical, conceptual, and practical issues", Administrative Science Quarterly, Vol.40, pp.309-342.

Hair, J., Anderson, R., Black, B., Babin, B., and Black, W. (2010), Multivariate Data Analysis, Pearson Education, London.

Hoang, D.T., Igel, B., and Laosirihongthong, T. (2006), "The impact of total quality management on innovation: Findings from a developing country", International Journal of Quality \& Reliability Management, Vol.23, No.9, pp.1092-1117.

Holmbeck, G.M. (1997), "Toward terminological, conceptual, and statistical clarity in the study of mediatings and moderators: Examples from the child-clinical and pediatric psychology literatures", Journal of Consulting and Clinical Psychology, Vol.65, No.4, pp.699-710.

Hung, R.Y.Y., Lien, B.Y.H., Yang, B., Wu, C.M., and Kuo, Y.M. (2011), "Impact of TQM and organizational learning on innovation performance in the high-tech industry", International business review, Vol.20, No.2, pp.213-225.

Jackson, S.A., Gopalakrishna-Remani, V., Mishra, R., and Napier, R. (2016), "Examining the impact of design for environment and the mediating effect of quality management innovation on firm performance", International Journal of Production Economics, Vol.173, pp.142-152.

Jayaram, J., Ahire, S.L., and Dreyfus, P. (2010), "Contingency relationships of firm size, TQM duration, unionization, and industry context on TQM implementation - A focus on total effects", Journal of Operations Management, Vol.28, No.4, pp.345-356.

Jiménez, D. and Sanz, R. (2008), “Could HRM support organizational innovation?”, The International Journal of Human Resource Management, Vol.19, No.4, pp.1208-1221.

Kafetzopoulos, D., Gotzamani, K., and Gkana, V. (2015), "Relationship between quality management, innovation and competitiveness. Evidence from Greek companies", Journal of Manufacturing Technology Management, Vol.26, No.8, pp.1177-1200.

Kim, D.Y., Kumar, V., and Kumar, U. (2012), "Relationship between quality management practices and innovation", Journal of Operations Management, Vol.30, No.4, pp.295-315.

Kozlowski S.W.J., and Klein K. (2000), “A multilevel approach to theory and research on organizations: Contextual, temporal, and emergent processes". In Klein KJ, Kozlowski SWJ (Eds.), Multilevel theory, research, and methods in organizations (pp. 3-90). San Francisco, CA: Jossey-Bass. 
Kumar, V. and Boyle, T. (2001), "A quality management implementation framework for manufacturing-based R\&D environment”, International Journal of Quality and Reliability Management, Vol.18, No.3, pp.336359.

Landis, R.S., Beal, D.J., and Tesluk, P.E. (2000), “A comparison approaches to forming composite measures in structural equation models", Organizational Research Methods, Vol.3, No.2, pp.186-207.

Laosirihongthong, T., Teh, P.L., and Adebanjo, D. (2013), "Revisiting quality management and performance", Industrial Management \& Data Systems, Vol.113, No.7, pp.990-1006.

Llach, J., Casadesus, M. and Marimon, F. (2011), "Relationship between quality-management systems and organizational innovations", Human Factors and Ergonomics in Manufacturing \& Service Industries, Vol.21, No.1, pp.52-66.

Maden, C. (2015), "Linking high involvement human resource practices to employee proactivity", Personnel Review, Vol.44, No.5, pp.720-738.

Manders, B., de Vries, H.J., and Blind, K. (2016), "ISO 9001 and product innovation: A literature review and research framework", Technovation, Vol.48-49, pp.41-55.

Martínez, M. and Martínez, A.R. (2008), "Does quality management foster or hinder innovation? An empirical study of Spanish companies", Total Quality Management, Vol.19, No.3, pp.209-221.

Menzel, H.C., Aaltio, I., and Ulijn, J.M. (2007), "On the way to creativity: Engineers as intrapreneurs in organizations", Technovation, Vol.27, No.12, pp.732-743.

Miles, R.E. and Snow, C.C. (1984), "Designing Strategic Human Resource Systems", Organizational Dynamics, Vol.13, No.1, pp.36-52.

Mir, M., Casadesús, M., and Petnji, L.H. (2016), "The impact of standardized innovation management systems on innovation capability and business performance: An empirical study", Journal of Engineering and Technology Management, Vol.41, pp.26-44.

Moreno, M.D., Gil, M., and Valls, J. (2013), “TQM, innovation and the role of cultural change”, Industrial Management \& Data Systems, Vol.113, No.8, pp.1149-1168.

Moreno, M.D. and Lloria, M.B. (2008), "The role of non-structural and informal mechanisms of integration and coordination as forces in knowledge creation", British Journal of Management, Vol.19 No.3, pp.250276.

Morgeson, F.P., and Hofmann, D.A. (1999), "The structure and function of collective constructs: Implications for multilevel research and theory development", Academy of Management Review, Vol.24, No.2, pp.249265.

Nair, A. (2006), "Meta-analysis of the relationship between quality management practices and firm performance-implications for quality management theory development", Journal of Operations Management, Vol.24, No.6, pp.948-975.

Naor, M., Goldstein, S.M., Linderman, K.W., and Schroeder, R.G. (2008), "The role of culture as driver of quality management and performance: infrastructure versus core quality practices", Decision Sciences, Vol.39, No.4, pp.671-702.

O’Neill, P., Sohal, A., and Teng, C. W. (2016), 'Quality management approaches and their impact on firms' financial performance-An Australian study”, International Journal of Production Economics, Vol.171, pp.381-393.

Ohly, S., Sonnentag, S., and Pluntke, F. (2006), "Routinization, work characteristics and their relationships with creative and proactive behaviors", Journal of Organizational Behavior, Vol.27, No.3, pp.257-279.

Ohly, S., and Fritz, C. (2007), "Challenging the status quo: What motivates proactive behaviour?", Journal of Occupational and Organizational Psychology, Vol.80, pp.623-629.

Ooi, K.B., Lin, B., Teh, PL., and Chong, A. Y.L. (2012), "Does TQM support innovation performance in Malaysia's manufacturing industry?", Journal of Business Economics and Management, Vol.13, No.2, pp.366-393.

Parker, S.K. (1998), "Role breadth self-efficacy: Relationship with work enrichment and other organizational practices", Journal of Applied Psychology, Vol.83, No.6, pp.835-852.

Parker, S.K. and Collins, C.G. (2010), "Taking stock: Integrating and differentiating multiple proactive behaviors", Journal of Management, Vol.36, No.3, pp.633-662.

Parker, S.K., Williams, H.M., and Turner, N. (2006), "Modeling the antecedents of proactive behavior at work", Journal of Applied Psychology, Vol.91, No.3, pp.636-652.

Parker, S.K., Bindl, U.K. and Strauss, K. (2010), "Making things happen: A model of proactive motivation", Journal of Management, Vol.36, No.4, pp.827-856.

Pekovic, S. and Galia, F. (2009), "From quality to innovation: Evidence from two French Employer Surveys", Technovation, Vol.29, No.12, pp.829-842. 
Perdomo, J., González, J., and Galende, J. (2009a), "The intervening effect of business innovation capability on the relationship between Total Quality Management and technological innovation", International Journal of Production Research, Vol.47, No.18, pp.5087-5107.

Perdomo, J., González, J., and Galende, J. (2009b), “An analysis of the relationship between total quality management-based human resource management practices and innovation", The International Journal of Human Resource Management, Vol.20, No.5, pp.1191-1218.

Pfeifer, T., Siegler, S., and Varnhagen, V. (1998), "Business excellence through a robust development process for innovative Products", Total Quality Management \& Business Excellence, Vol.9, No.4\&5, pp.191-194.

Podsakoff, P.M., Mackenzie, S.B., Lee, J.Y. and Podsakoff, N.P. (2003), "Common method biases in behavioral research: a critical review of the literature and recommended remedies", Journal of Applied Psychology, Vol.88, No.5, pp.879-903.

Podsakoff, P.M., MacKenzie, S.B., \& Podsakoff, N.P. (2012), "Sources of method bias in social science research and recommendations on how to control it", Annual Review of Psychology, Vol.63, pp.539-569.

Powell (1995), "Total Quality Management as Competitive Advantage a Review and Empirical Study", Strategic Management Journal, Vol.16, No.1, pp.15-37.

Prajogo, D.I., \& Ahmed, P.K. (2006), "Relationships between innovation stimulus, innovation capacity, and innovation performance", $R \& D$ Management, Vol.36, No.5, pp.499-515.

Prajogo, D.I and Cooper, B. (2010), "The effect of people-related TQM practices on job satisfaction: a hierarchical model", Production Planning \& Control, Vol.21, No.1, pp.26-35.

Prajogo, D.I. and Hong, S.W. (2008), "The effect of TQM on performance in R\&D environments: A perspective from South Korean firms", Technovation, Vol.28, No.12, pp.855-863.

Prajogo, D.I. and Sohal, A.S. (2001), "TQM and innovation: a literature review and research framework", Technovation, Vol.21, No.9, pp.539-558.

Prajogo, D.I. and Sohal, A.S. (2004), "The multidimensionality of TQM practices in determining quality and innovation performance - an empirical examination”, Technovation, Vol.24, No.6, pp.443-453.

Prajogo, D.I. and Sohal, A.S. (2006), "The integration of TQM and technology/R\&D management in determining quality and innovation performance", Omega, Vol.34, No.3, pp.296-312.

Pugh, S.D., and Dietz, J. (2008). "Employee engagement at the organizational level of analysis". Industrial and Organizational Psychology, Vol.1, No.1, pp.44-47.

Rahman, S.U., and Bullock, P. (2005), "Soft TQM, hard TQM, and organisational performance relationships: an empirical investigation", Omega, Vol.33, No.1, pp.73-83.

Ramus, C.A. and Steger, U. (2000), "The roles of supervisory support behaviors and environmental policy in employee "ecoinitiatives" at leading-edge European companies", Academy of Management Journal, Vol.43, No.4, pp.605-626.

Rigtering, J.P.C. and Weitzel, U. (2013), "Work context and employee behavior as antecedents for intrapreneurship", International Entrepreneurship and Management Journal, Vol.9, No.3, pp.337-360.

Sadikoglu, E. and Zehir, C. (2010), "Investigating the effects of innovation and employee performance on the relationship between total quality management practices and firm performance: An empirical study of Turkish firms", International Journal of Production Economics, Vol.127, No.1, pp.13-26.

Santos, M.L. and Álvarez, L.I. (2007), "Innovativeness and organizational innovation in total quality oriented firms: The moderating role of market turbulence", Technovation, Vol.27, No.9, pp.514-532.

Satorra, A. and Bentler, P.M. (2001), "A scaled difference chi-square test statistic for moment structure analysis”, Psychometrika, Vol.66, pp.507-514.

Sethi, R., and Sethi, A. (2009), “Can Quality- Oriented Firms Develop Innovative New Products?”, Journal of Product Innovation Management, Vol.26, No.2, pp.206-221.

Schuler, R.S. and Jackson, S.E. (1987), "Linking Competitive Strategies with Human Resource Management Practices", Academy of Management Executive, Vol.1, No.3, pp.207-219.

Sharma, B. (2006), "Quality management dimensions, contextual factors and performance: An empirical investigation", Total Quality Management and Business Excellence, Vol.17, No.9, pp.1231-1244.

Shin, Y. and Kim, M.J. (2015), "Antecedents and mediating mechanisms of proactive behavior: Application of the theory of planned behaviour", Asia Pacific Journal of Management, Vol.32, No.1, pp.289-310.

Silva, G.M., Gomes, P.J., Lages, L.F., and Lopes, Z. (2014), "The role of TQM in strategic product innovation: an empirical assessment", International Journal of Operations \& Production Management, Vol.34, No.10, pp.1307-1337.

Singh, P.J. and Smith, A.J.R. (2004), "Relationship between TQM and innovation: an empirical study", Journal of Manufacturing Technology Management, Vol.15, No.5, pp.394-401.

Slater, S.F. and Narver, J.C. (1998), "Customer-led and market-led: let's not confuse the two", Strategic Management Journal, Vol.19, No.10, pp.1001-1006. 
Song, Y. and Su, Q. (2015), "The relationship between quality management and new product development: evidence from China", Operations Management Research, Vol.8, No.1-2, pp.1-14.

Sonnentag, S. (2003), "Recovery, work engagement, and proactive behavior: A new look at the interface between nonwork and work", Journal of Applied Psychology, Vol.88, No.3, pp.518-528.

Speier, C. and Frese, M. (1997), "Generalized self-efficacy as a mediator and moderator between control and complexity at work and personal initiative: A longitudinal study in East Germany", Human Performance, Vol.10, No.2, pp.171-192.

Spencer, B.A. (1994), "Models of organization and total quality management: a comparison and critical evaluation", Academy of Management Review, Vol.19, No.3, pp.446-471.

Strauss, K., Griffin, M.A., and Rafferty, A.E. (2009), "Proactivity directed toward the team and organization: The role of leadership, commitment and role-breadth self-efficacy", British Journal of Management, Vol.20, pp.279-291.

Terziovski, M. and Guerrero, J. L. (2014), "ISO 9000 quality system certification and its impact on product and process innovation performance", International Journal of Production Economics, Vol.158, pp.197207.

Unsworth, K.L. and Parker, S.K. (2003), "Proactivity and Innovation: Promoting a New Workforce for the New Workplace", in Holman, D., Wall, T.D., Clegg, C.W., Sparrow, P., and Howard, A. (Eds.), The New Workplace. A Guide to the Human Impact of Modern Working Practices, John Wiley and Sons, Ltd, New York, pp.175-196.

West, M.A. (2002), "Sparkling fountains or stagnant ponds: An integrative model of creativity and innovation implementation in work groups", Applied Psychology, Vol.51, No.3, pp.355-387.

West, M.A. and Anderson, N.R. (1996), "Innovation in top management teams", Journal of Applied Psychology, Vol.81, No.6, pp.680-693.

Wood, S. and Albanese, M. T. (1995), "Can We Speak of a High Commitment Management on the Shop Floor?", Journal of Management Studies, Vol.32, No.2, pp.215-247.

Wu, C.H. and Parker, S.K. (2017), "The role of leader support in facilitating proactive work behavior: A perspective from attachment theory", Journal of Management, Vol.43, pp.1025-1049.

Wu, S.J. and Zhang, D. (2013), "Analyzing the effectiveness of quality management practices in China", International Journal of Production Economics, Vol.144, No.1, pp.281-289.

Zeng, J., Phan, C.A., and Matsui, Y. (2015), "The impact of hard and soft quality management on quality and innovation performance: An empirical study", International Journal of Production Economics, Vol.162, pp.216-226.

Zeng, J., Zhang, W., Matsui, Y., and Zhao, X. (2017), "The impact of organizational context on hard and soft quality management and innovation performance", International Journal of Production Economics, Vol.185, pp.240-251.

$\mathrm{Zu}, \quad \mathrm{X}$. (2009), "Infrastructure and core quality management practices: how do they affect quality?”, International Journal of Quality \& Reliability Management, Vol.26, No.2, pp.129-149. 